\title{
De andres sko
}

\author{
Blant norske leger er Kåre Moen mest kjent for Legevakthåndboken. Blant folk flest er han \\ kjent fra nettstedet Lommelegen. Nå jobber han med noe som inntil nylig har vært et nesten \\ helt forsømt tema - hivsmitte mellom menn som har sex med menn i Afrika.
}

«Åpen» er et ord mange bruker for å beskrive Kåre Moen, og det er det umiddelbare inntrykket han gir. «Travel» er allikevel mest betegnende. Det er ikke lett å få til en avtale med en mann som den ene måneden er i Afrika på jobb og den neste uken i Australia på ferie. Til slutt lyktes vi å få i stand et møte på Lorry. Det viser seg at han er hjemom iblant. Hjemme er en enebolig ved sjøen i Oslo.

- Vann er viktig for meg. Lyden av båtmotorer som sier dunk-dunk. Jeg liker å stirre på havet. Bølgeskvulp gir meg påfyll.

\section{Lege og journalist}

- Hvorfor valgte du å studere medisin?

- Jeg ville bli journalist og jeg ville bli lege. Det de alternativene har til felles, tror jeg, er det å være en del av menneskers liv.

- Har du noen journalistutdanning?

- Nei, men jeg utdannet meg litt selv. Det begynte med familieavis da jeg gikk på barneskolen. Den ble mangfoldiggjort på kopimaskinen på jobben til faren min og sendt til alle familiemedlemmer. Den kom ut i flere år. Det var da jeg oppdaget at det var spennende å være en skrivende person. Jeg har en veldig fin familie som skrev leserinnlegg og oppmuntret meg.

Moen har tilbrakt mye tid i Afrika, både som lege og stipendiat. Det første møtet med kontinentet fikk han tidlig.

- Hvorfor flyttet familien din til Kenya?

- Foreldrene mine jobbet for Norad. Første gangen de reiste ut, var da jeg gikk siste år på videregående skole.

- Hvordan var det første møtet med kontinentet?

- Jeg husker godt den første dagen. Alt var annerledes - fargene, luktene, menneskene og gatene. Jeg ble slått av det fantastiske i annerledesheten. Det gjorde et sterkt inntrykk på meg. I løpet av de par månedene jeg var der, begynte jeg å føle meg hjemme. Jeg hadde av en eller annen grunn en intuitiv følelse av å høre til også der.

\section{En bok blir født}

Først ble det allikevel medisinstudier i Bergen, senere turnus.

- Hvor kjørte du dine første legevakter?

- Det var i Tinn, etter at jeg først hadde vært i sykehusturnus på Rjukan. Det var egentlig der Legevakthåndboken begynte.

- Fortell.

- Jeg kjørte mine første legevakter, og det var et stort distrikt. Tanken på å være der ute alene i mørket - alt som kunne skje - var nokså skremmende. Jeg hadde en kasse full av bøker i bagasjerommet. - Hele fagbiblioteket?

- Det som fikk plass i en banankasse. Jeg følte behov for å ha referanselitteratur tilgjengelig. Jeg og Cecilie Arentz-Hansen snakket om alle utfordringene ved legevakt. Vi ønsket oss en bok som var tilpasset denne typen legejobb, der jo alt kan skje. Det viste seg at den ikke fantes.

- Og da kom ideen om å lage den selv?

- Den dukket opp flere ganger. En tidlig søndag morgen sluttet vi å snakke og begynte å skrive. Først laget vi et par kapitler, sendte dem til Universitetsforlaget og forklarte bakgrunnen for ideen. Etter bare noen dager fikk vi svar om at de ville lage bok med oss. Jeg hadde søkt på og fått jobb i Tanzania og ville nødig si nei til verken jobb eller bok. Jeg foreslo for Cecilie at vi kunne dele. Hun slo til, og vi flyttet begge til Tanzania. Det skulle bygges et større vannkraftverk, og vi skulle etablere og drive en klinikk for de ansatte. Vi jobbet og skrev. Ofte var det ikke strøm. Det fantes ikke e-post. Vi sendte manus frem og tilbake i posten.

- Det var en stor jobb?

- Ja, og hvis ikke vi hadde gjort det da, tror jeg knapt vi ville fătt gjennomført det. Vi hadde nettopp levd med behovet for boken, følt det på kroppen. Midt på natten trenger man en håndterbar bok med umiddelbare råd som dekker veldig bredt tematisk. Hvis den hovedsakelig var blitt til ved et skrivebord, tror jeg fort den ville blitt altfor stor og dessuten mindre praktisk rettet.

- Hvordan føles det å være forfatter av en bred bok som nesten alle landets leger har i legevaktkofferten? Var dere redde for at det skulle stå noe der som var feil?

- Ja, men jeg var kanskje ikke så redd som jeg burde ha vært. Boken har visstnok vært normativt brukt til og med i en rettssal.

\section{Folkehelse i Tanzania}

Det som begynte med en klinikk for ansatte ved et vannkraftverk i Tanzania, utviklet seg til å bli noe mer.

- Vannverket hadde 2000 ansatte, mest menn. De aller fleste var innflyttere. For lokalsamfunnet var det en kjempeomveltning. De ansatte var i et sosialt limbo og de var relativt pengesterke. Det var en utfordring på mange måter - særlig med tanke på hivsmitte, hygiene og trafikk.

- Hva var din oppgave?

- Det var å starte og drive bedriftslegevirksomhet for de ansatte. Det var viktig, men jeg ble enda mer interessert i folkehelseproblemene vannkraftprosjektet førte med seg. - Du tok en mastergrad i folkehelse allerede under medisinstudiet?

- Jeg var hele tiden interessert i samfunnsmedisin. Jeg ble nok inspirert av oppholdene i Afrika. Jeg var blitt opptatt av hvor urettferdig verden er. Helt fra like før jeg begynte på studiet tenkte jeg det ville være viktig og meningsfylt å jobbe med helseutfordringer i land med få materielle ressurser.

- Det ble til slutt folkehelsearbeid i Tanzania?

- Ja. Utbyggerne hadde gjort miljøkonsekvensutredninger med tanke på naturen. Vi pekte på at de hadde glemt det humane miljøet og laget en helsekonsekvensutredning for lokalsamfunnet, i et samarbeid med distriktshelsetjenesten i området. Vi laget spørreundersøkelse, møtte alle landsbylederne, hadde folkemøter hvor vi diskuterte hvordan folk så på situasjonen som den var. Deretter laget vi et forslag til helseprogram, som raskt ble vedtatt.

Verdensbanken var imponert og konkluderte med at prosjektet var flere år forut for sin tid.

\section{Lommelege}

- Du er kanskje aller mest kjent for nettstedet Lommelegen.no. Hvordan kom dette til?

- Etter Legevakthåndboken laget vi en bok som het Lommelegen, en tilpasning av en legetekst for folk flest. Nettstedet begynte litt tilfeldig. Det var tidlig i Internettutviklingen. Vi la ut noen av kapitlene på nett, og så viste det seg at vi fikk masse besøk.

- Hva var motivasjonen for å drive et nettsted om helse?

- Det var en fascinerende måte å gjøre noe med assymetrien i tilgang til medisinsk kunnskap mellom helsepersonell og folk 


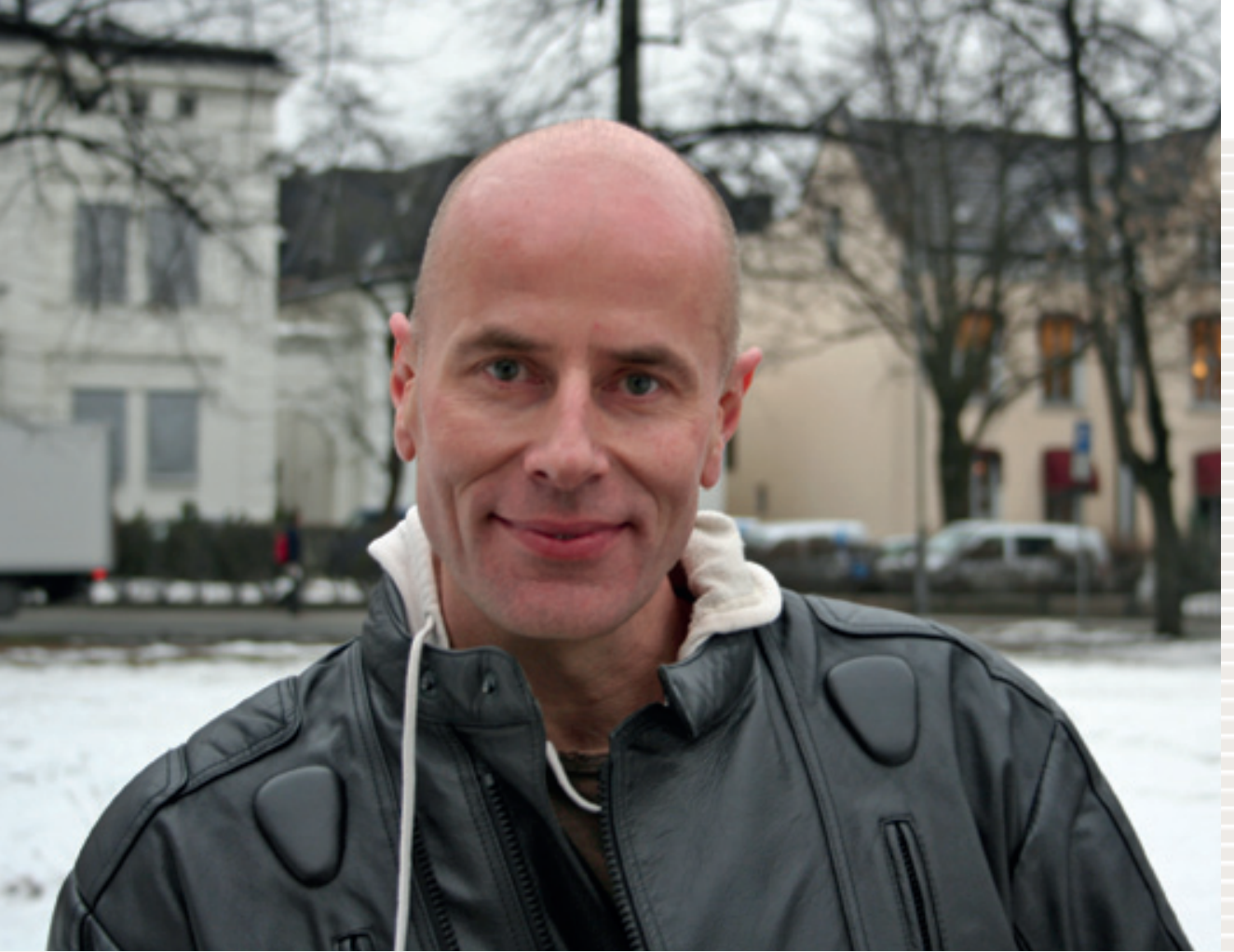

flest. Det å gjøre den medisinske kunnskapen tilgjengelig for flere, syntes vi var viktig. Men prosjektet ble fort mye større enn vi hadde sett for oss. Bruken av nettstedet vokste foran øynene på oss. Vi måtte sette oss ned og se på hvordan vi kunne drive det. Vi hadde jo ingen finansiering. Løsningen ble reklame.

- Dere har trukket dere ut nå?

- Det var en fin og viktig ting å jobbe med, men ingen av oss følte vi skulle prioritere Lommelegen for alltid. Det var bra at noen ville overta nettstedet.

- Ser du noen ulemper ved at det finnes så enorme mengder helseinformasjon på nettet, med varierende grad av kvalitetssikring? Kan det bidra til feilinformasjon og redsel?

- Jo, men på den måten reflekterer vel Internett virkeligheten. Vi får jo stadig høre ting som er mer eller mindre reflektert og sant. En grunnleggende menneskelig kompetanse er å forholde seg til akkurat det. Tanken på at man kunne lage endelig og riktig informasjon om alt for alle, er helt umulig. Jeg synes at et ganske typisk trekk ved folk er at de ikke forholder seg ukritisk til medisinsk informasjon. Noen ganger ender kjeden med at man er pasient på legekontoret $\mathrm{g} g$ har med seg en utskriftsbunke. Det er fint. Da er man engasjert i sin sykdom.

- Hvordan påvirkes legerollen av dette?

- Det er nok ingen lys fremtid for en lege som tenker at han er den eneste som vet noe. Den måten å være lege på, er ikke levedyktig i et informasjonssamfunn. Man må ha god faglig kunnskap, erkjenne at man ikke er den eneste som har det, og forsøke å tenke seg hvordan det er å være i skoene til den som kommer til legen. Legen kan spørre om å få ta dem på. Skal man være en god lege, bør man nok prøve å få det til.

\section{Hiv i Afrika}

- Hva går forskningsprosjektet ditt ut på?

- Det handler om hiv og menn som har sex med menn i Dar-es-Salaam.
- For noen år siden trodde man ikke det var en problemstilling?

- Det har vært nokså vanlig å tenke at det nesten ikke finnes homoseksualitet i Afrika. - Hvorfor var det slik?

- Si det. I Vesten har det vært en tradisjon for å tenke at Afrika og afrikanere er annerledes enn oss. De som først skrev om homoseksualitet og Afrika, var vestlige oppdagere, misjonærer og antropologer.

Ikke alle hadde vært på det afrikanske kontinentet selv engang, men de slo fast at homoseksualitet ikke fantes der. Noen laget kart over hele verden om hvor homoseksualitet forekom. Afrika var ikke med. Denne forestillingen har stått sterkt siden, og i hivepidemien har den bidratt til at vi som profesjon har forsømt oss grovt. Den første studien av hivprevalens blant menn som er sammen med menn i Afrika ble gjort så sent som i 2005, 20 år inn i epidemien.

- Hvorfor begynte du å forske på dette?

- Jeg synes jo det var rart at hivepidemien skulle arte seg så annerledes der, og kunne etter hvert ikke tro at det var slik. - Homoseksualitet beskrives som tabu i Afrika. Hvordan får du folk til å snakke?

- Det har vært sagt, skrevet og tatt for gitt at dette er et tema det er vanskelig å snakke om i Afrika, og at menn som har sex med menn der er vanskelige å nå. Men det stemmer ikke, i hvert fall ikke i Tanzania. I planleggingsfasen lurte vi mye på om prosjektet var gjennomførbart. Det var bygd på en ikke-informert antakelse. I virkeligheten kan man snakke med tanzanianere om homofili.

\section{- Hva slags feltarbeid gjør du?}

- Det er en blanding av ulike kvalitative forskningsmetoder med deltakende observasjon som kjerne, en typisk antropologisk metode. Jeg bruker tid sammen med mennesker og deltar i hverdagslivet. I tillegg har jeg gjort mer formelle intervjuer og gruppediskusjoner. Det er blitt et stort kvalitativt materiale.

\section{Kåre Moen}

Født 2. mai 1963

- Cand.med. Universitetet i Bergen 1989

- Mastergrad i folkehelse fra University of California, 1989

- Grunnlegger av nettstedet Lommelegen.no

- Folkehelsearbeid i Tanzania 1992-2006

- Forfatter av Legevakthåndboken

- Stipendiat ved Universitetet i Oslo fra 2008

Foto Marit Tveito

- Hva håper du skal komme ut av det?

- Målet er å forsøke å beskrive og forstå verden slik den ser ut fra disse mennenes utsiktssted, og det mangfoldet av tanker, følelser og utfordringer som preger dem og deres forhold til hiv.

\section{Å prøve sko}

Moen reiser mye og har alltid holdt på med mange ting på én gang.

- Hva blir du sliten av?

Han tenker seg lenge om og smiler. - Jeg tror ikke jeg blir så sliten.

- Er det plass til noen andre i livet ditt?

- Jeg har en samboer, Truls. Han er en viktig del av livet mitt. Han er en fleksibel person som gjør mange ting selv, men som også har evnen til å glede seg over det jeg gjør.

- Hva gjør du for å håndtere mangfoldet av interesser? Blir det så bredt at du blir grunn?

- Noen ganger finner man kanskje dybden i bredden. Faglig sett er jeg veldig fokusert akkurat nå. Det å være stipendiat $i$ et forskningsprosjekt er veldig konkret. Selv om jeg har gjort mye forskjellig, er det noe som binder det sammen. Kanskje er det nysgjerrigheten, eller det å gå i andres sko. For å være en god formidler må du kunne se for deg hvordan det er å ha skoene på. Legevakthåndboken ble til fordi vi hadde gått i legevaktlegens sko. Det å forske og bruke deltakende observasjon som metode er som å prøve å gå i andres sko.

Han stopper opp og tenker seg om. - Kanskje gjør jeg egentlig det samme hele tiden.

\section{Marit Tveito}

marit.tveito@diakonsyk.no

Psykiatrisk avdeling, Vinderen

Diakonhjemmet sykehus 